Журнал «Герспективитаінноваціїнауки»

(Серія«Гедагогіка»), Серія«ГТихологія», Серія «Медицина»

№5(5) 2021

УДК 378

https://doi.org/10.52058/2786-4952 -2021-5(5)-644-655

Чепок Роман Володимирович кандидат педагогічних наук, доцент, завідувач кафедри професійної освіти, Херсонський державний аграрноекономічний університет, вул. адм. Сенявіна 148/2, м. Херсон, 73000, тел.: (050) 979-60-60, e-mail: yastrubrv@gmail.com, https://orcid.org/ 0000-0002-90633244

\title{
МЕТОДИКА ПРОФЕСІЙНОЇ ОСВІТИ ЯК НАУКОВА ГАЛУЗЬ ПЕДАГОГІЧНИХ ЗНАНЬ ТА ІСТОРІЯ ЇЇ РОЗВИТКУ
}

Анотація. Процеси європейської інтеграції охоплюють дедалі більше сфер життєдіяльності, включно професійно-технічну освіту. Україна чітко визначила орієнтир на входження в освітній і науковий простір Європи, здійснює модернізацію освітньої діяльності в контексті європейських вимог, дедалі наполегливіше працює над практичним приєднанням до європейського освітнього простору.

Якщо майбутнє України пов'язане з Європою, то не можна надалі стверджувати, що освітній процес має для України лише просвітнє та пізнавальне значення. Надання високої оцінки національній системі освіти не повинне стримувати глибинне іiі реформування.

Висока якість навчання - це досягнення попередньої епохи, попередньої системи влади, попереднього покоління. Нині можна $з$ жалем констатувати, що незважаючи на природні досягнення освіти, які забезпечує нова соціополітична система, в масовому вимірі освіта стала менш якісною, а переважна більшість випускників навчальних закладів (особливо нових) не конкурентоспроможна на Європейському ринку праці. Це зобов'язує менше говорити про власні досягнення, а все більше аналізувати світові та європейські тенденції реформування освіти i відповідно до цього напружено i послідовно вдосконалювати нашу професійну сферу діяльності.

Вирішальним фактором змін в освіті завжди буде людина і ії професійна якість. Тому так важливі сьогодні глибокі знання вчителя, його педагогічний досвід і майстерність, що є «основною ланкою» майбутніх реформ.

Вище сказане повною мірою ставиться й до викладача професійного закладу освіти.

Методиці професійної освіти з давніх часів приділялося багато уваги. За часів Козацької Січі існували специфічні засоби та прийоми навчання професійних навичок. Із плином часу сфера професійної діяльності зростала, розгалуженість професійних умінь збільшувалась, а отже розвивалася і методика.

В науковій роботі методику професійного навчання розглянуто як самостійну галузь педагогічних знань про застосування та розвиток спеціальних 
засобів регуляції освітньої діяльності педагога. У процесі формування та розвитку професійних знань та умінь відбувається взаємодія особистості педагога як носія прийомів, методик та технологій навчання. Професійноособистісна взаємодія викладача та учнів тісно пов'язана із змістово-дієвою стороною навчання, утворюючи за допомогою спеціально розроблених засобів навчально-виховну ситуацію, що здійснює вплив на результати навчання.

Ключові слова: професійна освіта, методика викладання, освітній простір, психолого-педагогічна думка, історична формація, професійнопедагогічна діяльність.

Chepok Roman Volodymyrovych PhD, Associate Professor Kherson state agrarian and economic university, Strytenska Ave., 22, Kherson, 73000, e-mail: Ystrubrv@gmail.com, tel.: (050) 979-60-60, https://orcid.org/0000-0002-9063-3244

\section{METHODS OF VOCATIONAL EDUCATION AS A SCIENTIFIC FIELD OF PEDAGOGICAL KNOWLEDGE AND HISTORY OF ITS DEVELOPMENT}

Abstract. The processes of European integration cover more and more spheres of life, including vocational education. Ukraine has clearly defined the benchmark for entering the educational and scientific space of Europe, modernizes educational activities in the context of European requirements, and is working harder and harder to practically join the European educational space.

If Ukraine's future is connected with Europe, it cannot be further stated that the educational process is of only educational and cognitive significance for Ukraine. High praise for the national education system should not hinder its deep reform.

High quality education is the achievement of the previous era, the previous system of government, the previous generation. It is now unfortunate that, despite the natural achievements of education provided by the new socio-political system, education has become lower in quality, and the vast majority of graduates (especially new ones) are not competitive in the European labor market. This requires less talk about our own achievements, and more and more to analyze global and European trends in education reform and, accordingly, to intensively and consistently improve our professional field.

The decisive factor in changes in education will always be the person and his professional quality. That is why the teacher's deep knowledge, pedagogical experience and skills are so important today, which is the "main link" of future reforms.

The above fully applies to the teacher of a professional educational institution.

Much attention has been paid to the methodology of vocational education since ancient times.During the time of the Cossack Sich, there were specific tools and techniques for teaching professional skills. Over time, the sphere of professional activity grew, the branching of professional skills increased, and thus the 
methodology developed.

In the scientific work the method of professional training is considered as an independent branch of pedagogical knowledge about the application and development of special means of regulating the educational activities of teachers. In the process of formation and development of professional knowledge and skills there is an interaction of the teacher's personality as a carrier of techniques, methods and technologies of teaching. Professional and personal interaction between teacher and students is closely related to the content and effectiveness of learning, creating with the help of specially designed tools educational situation that affects the learning outcomes.

Keywords: professional education, teaching methods, educational space, psychological and pedagogical thought, historical formation, professional and pedagogical activity.

Постановка проблеми. Становлення української держави, зміцнення іiі позицій на світовій арені, пов'язане 3 швидкими темпами розвитку науки та техніки, ставить нові вимоги щодо якості професійної підготовки підростаючого покоління. Кардинальні соціально-політичні зміни, актуалізація питань державотворення і духовного відродження нації, перехід до нових форм економічного життя висувають на чільне місце проблеми освіти. Докорінна зміна підходів до неї і соціальної політики в цілому, яку переживає сучасний світ, акцентує увагу на розвитку людини, іiі особистісних якостях. Людина вічний творець духовних і матеріальних благ, носій цивілізації, ії політичного і освітнього поступу. Створення європейського ринку праці вимагає сьогодні від будь-якого члена суспільства насамперед професіоналізму, творчості, максимального розкриття і використання внутрішнього потенціалу особистості.

Характеризуючи сучасний освітній процес, слід підкреслити, що кризові явища, які найбільш яскраво проявляються в останні десятиріччя, є наслідком відставання його від науки, виробництва та суспільства. Освіта опинилася у двозначному становищі: 3 одного боку, вона обумовлює науково-технічний прогрес, а 3 другого - в надрах самого освітнього процесу чітко виявляється тенденція до внутрішнього опору інноваційним явищам у власній галузі.

Одне із головних положень концепції оновлення сучасної освіти пов'язане 3 перебудовою професійно-технічної освіти в галузі управління та ведення сільського господарства, оскільки знання і вміння по веденню господарчої справи - це один із факторів, що сприяють загальноекономічному розвитку людини, ії готовності до неперервної професійної діяльності.

Оскільки методика є динамічною наукою, актуальність даної роботи полягає у вивченні сучасних аспектів та особливостей викладання у професійно-технічних навчальних закладах, аналізі їх ефективності та пропозиції власних прийомів та методів організації роботи для оптимізації навчального процесу. 
Аналіз останніх досліджень і публікацій. Важливі аспекти формування та розвитку сучасної професійної освіти висвітлюються такими українськими ученими як О.Коваленко, Н.Брюханова, Т.Дороніна, В.Сидоренко, Н.Слюсаренко. Однак історичний аналіз та впровадження особливостей викладання у професійних закладах освіти поки що не систематизовані i розроблені не в повному обсязі.

Мета статті - розкрити теоретичні засади методики викладання у професійно-технічних навчальних закладах у історичному аспекті їхньої формації.

На шляху до реалізації поставленої мети мають бути вирішені наступне завдання: розкрити історію розвитку професійних закладів освіти, описати специфіку методики професійної освіти як наукової галузі педагогічних знань.

Виклад основного матеріалу. Історія розвитку методичних знань має велике світоглядне та виховне значення у підготовці професійно-педагогічних кадрів. В історії розвитку методичних знань вчені виділяють сім періодів. У основу періодизації покладено провідні підходи до викладання, методи та технології навчання, властиві для даного періоду.

У метричному відношенні кожен період характеризується кількістю учених-педагогів, що активно працюють над тим чи іншим методом, системою навчання; кількістю публікацій 3 апробації впроваджуваного у практику навчання методу чи системи навчання; наявністю науково-дослідних центрів, що працюють над впровадженням систем професійного навчання, лабораторій, вищих навчальних закладів, які $\epsilon$ споживачами методичних знань, що розвиваються. Тривалість кожного періоду (відрізок часу, за якого розвивається той чи інший метод навчання) складає в середньому близько 23 років.

Перша половина XVIII ст. Аналіз відповідних джерел свідчить, що до першої половини XVIII ст. не існувало окремих видань з методики навчання певному ремеслу. Можна вважати, що провідним методичним прийомом був прийом копіювання роботи майстра. Основні методичні ідеї в області професійної підготовки даного періоду описані педагогами-практиками Л.Ф. Магніцьким, В.Н. Татищевим.

Перша половина XVIII ст. - 60-i pp. XIX ст. Під впливом бурхливого розвитку промисловості стала формуватися мережа професійних навчальних закладів. Для підготовки кваліфікованих робітників необхідно було розробити методику виконання виробничих робіт, що підлягали вивченню. Підготовка робітників для потреб виробництва здійснювалась шляхом індивідуального учнівства, за якого навчання зводилось до безсистемного пояснення майстра. У якості методичної системи застосовувалась система виробничого навчання. Вона отримала поширення під впливом теоретичних робіт та методичного досвіду К. Ю. Цируля, Н. В. Касаткіна.

60-i pp. - кінець 90-х pp. ХІХ ст. Третій період розвитку методичних знань характеризується появою першої науково-обгрунтованої системи виробничого 
навчання. Група інженерів навчальних майстерень технічних училищ, до яких входили А.П. Платонов, А.М. Михайлов, В.П. Марков, Д.К. Совєткін, розробила у 1868 р. систематичний метод викладання механічних мистецтв. Апробований в училищах метод навчання ремеслу було застосовано вже у 70-х pp. у технічних училищах i схвалено як програмний метод навчання. При поширенні цього методу на Заході та в Америці ця система виробничого навчання дістала назву прогресивної системи. Зараз у науково-методичній літературі вона відома як операційна система виробничого навчання. Методика професійного навчання збагатилася у цей період системою комплексних операцій 3 підготовки кваліфікованих спеціалістів. Було обгрунтовано застосування системи вправ з формування практичних знань, умінь та навичок.

90-i pp. ХІХ ст. - кінець 30-х pp. ХХ ст. У цей період одночасно із формуванням системи професійної освіти почалось становлення методики виробничого навчання як самостійної галузі педагогічних знань. Роботу над удосконаленням системи виробничої освіти вели С.А. Володимирський, П.І. Устинов, Г.Ю. Гессе та ін.

У цей період стала відчутною необхідність у науково обгрунтованій системі методичних знань. 20-і pp. минулого століття були відзначені становленням та розвитком спеціальної педагогічної освіти. До змісту 3 психолого-педагогічної підготовки поряд з педагогікою та психологією було включено методику викладання спеціальних дисциплін. М.М. Рубінштейн обгрунтував побудову наукової системи методичних знань. Він запропонував до загально-методичної підготовки майбутніх інженерів-педагогів додати філософію та методологію технічних наук, історію техніки, анатомофізіологічні відомості про людину. На заключному етапі навчання майбутніх інженерів-педагогів вони мали вивчати окремі методичні питання, пов'язані 3 викладанням окремих дисциплін.

Проведений у 1924 р. з’ізд з робітничої освіти узагальнив накопичений досвід i результати дискусій 3 напряму розвитку методики виробничого навчання. На з'ізді було розроблено концепцію з підготовки кваліфікованих робітників. До основи концепції відбору змісту до програм виробничого навчання було покладено трудову операцію як основу навчання; до основи методології виробничого навчання - процесуальність, а не предметність. У майстерні учень отримував так звану обробно-виробничу настанову, тобто вивчались основні виробничі процеси та набувалися навички шляхом вправ (тренування) за основними операціями. Далі учні отримували організаційновиробничу настанову, тобто оволодівали поопераційним аналізом, самоконтролем, обліком, роботою за інструкційними картами та кресленнями. Створений на початку 20-х рр. минулого століття Центральний інститут праці (ЦІТ) 3 перших днів свого існування зосередив увагу на двох проблемах організації виробничого навчання:

$$
\text { побудова «лабораторного методу на виробництві»; }
$$


- розробка системи раціонального навчання кваліфікованих робочих та інструкторів.

30-і - кінець 50-х рр. ХХ ст. Цей період характеризується появою єдиної державної системи підготовки кваліфікованих робітників, що дала потужний поштовх розвиткові методики професійного навчання. Великої уваги стали приділяти розробці змісту професійної освіти. Кваліфікаційні характеристики за робочими професіями розглядались як форма держзамовлення на підготовку робітника. До основи виробничого навчання було покладено операційнокомплексну систему виробничого навчання, що застосовувалась ще на початку 30-х pp.

У 1930 р. було відкрито ряд інститутів в складі яких були інженерно педагогічні факультети, які мали за мету підготувати викладачів технічних та спеціальних дисциплін і майстрів виробничого навчання. У цей період активно розвивались погляди на теоретичні основи методичної підготовки майбутніх інженерів-педагогів. О.О. Красновський та С.Я. Купідонов підкреслювали, що методична підготовка має забезпечуватися окремими методиками, що різняться за складом та змістом залежно від спеціальності. Інша точка зору на побудову методичного знання належить А.Ф. Євстігнєєву-Бєлякову. Він визначив, що окремі та спеціальні методики навчання мають будуватися на двох підставах: на методології даної науки та психофізіологічних особливостях аудиторії.

Досвід розвитку теорії та практики методики виробничого навчання дозволив на початок 50-х рр. створити загальний курс методики виробничого навчання. У 1953 р. видано систематизований курс «Методика виробничого навчання», підготовлений провідними методистами системи трудових резервів під керівництвом А.М. Вейсбланда. Поширювались дискусії щодо впровадження до виробничого навчання класно-урочної системи, щодо методів виробничого навчання і щодо самої методики виробничого навчання. Усе це сприяло розвиткові методики професійної освіти як науки.

60-і - кінець 80-х рр. ХХ ст. У зв’язку з удосконаленням виробничих технологій система професійно-технічної освіти вимагали змін не лише у структурі, але і у змісті освіти. Найважливішою особливістю нових програм була спрямованість їх на широкий розвиток самостійних творчих робіт учнів. Змінювався підхід до виробничого навчання: від операційно-комплексної до нових систем виробничого навчання - конструкторсько-технологічній, технологічній і т.п. (В.К. Сидоренко)

У 1960-1970 рр. вчені обгрунтували цілий комплекс нових систем виробничого навчання: предметно-технологічну (І.Д. Клочков, М.А. Жиделєв), проблемно-аналітичну (С.Я. Батишев), прийомо-комплексно-видову (К.Н. Катханов) та ін. Ідею типізації технологічних процесів, запропоновану ще у 1930-х рр. проф. О.І. Соколовським, було покладено в основу одного 3 перспективних напрямів у технології машинобудування. Проблемноаналітична система поширилася у $60-70$ рр. під час підготовки робітників 
автоматизованого виробництва. Її розробив С.Я. Батишев. Ця система сприяла розвиткові інтелектуальних умінь та навичок, які відігравали усе більшу роль у праці висококваліфікованих робітників. Проблемно-аналітична система виробничого навчання надавала можливість дати теоретичне обгрунтування технологічним процесам, що вивчалися, надавала процесу навчання політехнічну спрямованість та підвищувала вимоги до загальноосвітньої підготовки, до рівня професійної освіти майбутніх робітників, сприяла їх усесторонньому розвиткові.

Широке поширення у професійно-технічних училищах на той час отримали різноманітні тренажери для формування індивідуальних професійних навичок роботи. Одним із засобів підвищення ефективності уроків виробничого навчання став письмовий інструктаж, який почав знову активно використовуватись 3 кінця 1960-х рр.

На початку 80-х pp. XX ст. велику увагу стали приділяти теорії та практиці міжпредметних зв'язків, що сприяли значному підвищенню ефективності уроків теоретичного та виробничого навчання і створювали можливості педагогам уникнути зайвого повторення навчального матеріалу.

У 1980-х рр. формувалась концепція бінарного уроку, що відображала специфіку професійного навчання. Основні роботи за цим напрямом виконувались під керівництвом професора Н.М. Таланчука. Власне H.M. Таланчук створив нову форму організації навчальної та навчальновиробничої діяльності, яка підготувала підгрунтя для впровадження у практику професійної освіти технологію модульного навчання та концентрованого навчання.

Розвиток теорії інтеграції у навчання, поява нових інтеграційних форм взаємодії педагога та учнів у процесі формування теоретичних знань та практичних умінь і навичок підготували основи для інтеграції методики виробничого та теоретичного навчання.

1990-і pp. - наш час. У 1990-і pp. розвивались інтеграційні процеси у теорії та практиці професійної освіти, знання та уміння проектувальної педагогіки (В.С. Безрукова, Д.О. Тхоржевський), педагоги-практики отримали можливість розробляти авторські навчальні програми та авторські методики навчання. У ці роки І.А. Халіуллін обгрунтував модель інтегративного уроку як цілеспрямовану взаємодію та інтеграцію діяльності різних учасників навчального процесу для вирішення задач навчально-пізнавальної та навчально-виробничої діяльності учнів. Інтегративний урок проводився викладачем загальноосвітніх дисциплін, інженером-педагогом, а майстер виробничого навчання показував технологію монтажу, обслуговування або ремонту обладнання.

У даний період до навчальної діяльності викладачів та майстрів виробничого навчання увійшли опорні конспекти, листки робочих зошитів, структурно-логічні схеми, задачі 3 міжпредметним змістом, узагальнені алгоритми виконання навчально-виробничих робіт, навчальні евристичні 
програми $[3,4]$.

У наступному періоді свого розвитку методика професійного навчання удосконалювала підходи, принципи та методи професійного навчання, виходячи на рівень технологічності та інформатизації. Інновації у професійній освіті стали джерелами розвитку технологічного підходу у навчанні і появи перших професійно-педагогічних технологій. Завдяки науково-дослідному пошуку учених, до професійної підготовки спеціалістів стали долучатися модульні технології навчання, технології концентрованого навчання, дистанційного навчання, авторські технології навчання педагогів професійної освіти. Крім основної функції - навчання професії - у педагогів професійної школи з'являються нові види професійно-педагогічної діяльності, значення яких для розвитку освітніх програм навчальних закладів зростатиме. До них належать: створення моделей спеціалістів, розробка програм розвитку навчального закладу, пошук та розробка технологій професійного навчання, проектування змісту навчання. Ускладнення праці професійно-педагогічних кадрів обумовило необхідність професійної підготовки педагогів-технологів.

Методика професійного навчання $\epsilon$ найважливішим компонентом професійної підготовки педагогів професійної школи. Методичні знання обслуговують професійну діяльність викладача i майстра виробничого навчання, тісно пов'язані з прийомами, методами цієї діяльності і, звісно ж, 3 особистістю самого педагога і його творчістю.

Вища освіта не забезпечує повної системи професійних знань 3 усіх професій. Відомі випадки, коли студентам під час педагогічної практики важко проводити заняття зі спеціальних дисциплін. Звідси великий попит у молодих педагогів на методичні розробки, де подано не методичну систему забезпечення формування нових знань, а розкривається готовий зміст навчального матеріалу.

Вочевидь, проблема полягає не в тому, щоб педагоги професійного навчання вивчили зміст усіх технічних дисциплін, включених до навчальних планів професійних училищ, а у тому, щоб навчити працювати 3 навчальним матеріалом, прийомам та методам формування технічних знань та професійних умінь та навичок [2].

Для того щоб представити теоретичну систему знань 3 методики професійного навчання, необхідно визначити об'єкт, предмет, побудову понятійно-термінологічного апарату, методи вивчення практичної роботи педагогів. Об'єктом пізнання методики професійного навчання є процес навчання конкретної дисципліни у навчальному закладі.

Відмінності методики навчання та педагогіки слід шукати в сутності навчальної діяльності педагога-предметника та методичній діяльності педагога-методиста. Предметом діяльності педагога-предметника є організація процесу навчання з предмету (рис. 1). 
Журнал«Герспективита інновації наукиљ

(Серія«Гедагогіка», Серія«ПЕихологія», Серія «Медицина»

№5(5) 2021

Викладач-предметник організує когнітивну (навчальну) діяльність учнів на основі змісту і відповідних методів навчання. Результатами навчальної діяльності виступають навчений учень, його система професійних знань та умінь, розвинена особистість та професійні здібності [1].

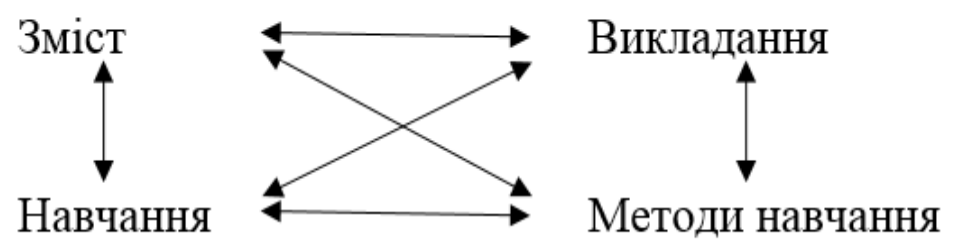

\section{Pис. 1. Взаємозв'язок основних компонентів процесу навчання}

Викладач-методист організує взаємодію діяльності викладачапредметника та діяльності учнів 3 метою формування нових знань та умінь. Взаємодію можна спланувати та організувати за допомогою спеціально розроблених засобів, що застосовуються у навчанні. Засоби навчання у широкому сенсі оптимізують процес навчання 3 предмету і забезпечують отримання запланованих результатів навчання на уроці. Таким чином, результатом методичної діяльності є спеціально розроблені засоби навчання, що утворюють «канал», за яким відбувається регуляція навчальної діяльності педагога та когнітивної діяльності учнів із засвоєння професійних знань, умінь та навичок.

Отже, предмет пізнання методики професійного навчання - це відносно самостійна галузь педагогічних знань і умінь про конструювання, застосування та розвиток спеціальних засобів навчання, за допомогою яких здійснюється регуляція навчальної діяльності викладача (майстра виробничого навчання) та когнітивної діяльності учнів з формування професійних знань та умінь і розвитку учнів.

Значну роль у розвитку практики методичної роботи педагога та ії теоретичного осмислення, обгрунтування відіграє система понять та співвіднесених з нею термінів. Поняття - це форма мислення, що відображає суттєві властивості і зв'язки явищ, це одиниця мислення. Будь-яке пізнання здійснюється людиною як формування понять та їх зв'язків. Термін - це слово або словосполучення, що точно визначає певне наукове поняття [5].

При упорядкуванні понятійно-термінологічного апарату методики професійного навчання може бути запропоновано декілька підстав для класифікації. Ми розглянемо класифікацію за джерелами формування, відповідно до якої виділяють три групи понять та термінів (рис. 2).

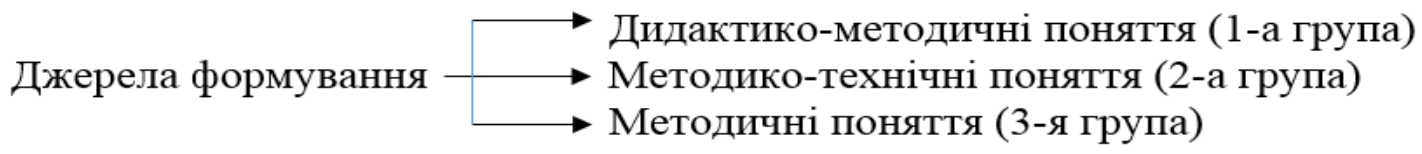

Pис. 2. Класифікаиія методичних понять 
До першої групи відносяться терміни, що прийшли у методику з базових наук: дидактики, теорії виховання, педагогічної психології та ін. Поняття та терміни, що застосовуються методикою у науці, що викладається, тобто в технічних науках, а також споріднених з ними - фізиці, математиці, утворюють другу групу - методико-технічні поняття. До третьої групи понять відносяться власне методичні поняття та терміни.

Дидактико-методичні поняття використовуються у методиках викладання різних предметів і видозмінюються стосовно кожного предмету, наприклад, у дидактиці - цілі навчання, розвиваюче навчання, у методиці - цілі навчання електротехніці, розвиток технічного мислення.

Наведемо приклади дидактико-методичних понять: формування технічного світогляду учнів; наочність у навчанні технічної механіки; знання учнів зі спеціальної технології; зміст предмету з електротехніки и т.д.

Другу групу утворюють методико-технічні, або техніко-методичні поняття, що спираються на технічну та технологічну термінологію. Ї̈ї складають поняття та терміни науки, що викладається, - техніки. Вони визначають назви об'єктів вивчення, тобто розділів, тем чи підтем уроків, або назви технічних та технологічних явищ, процесів, які входять до кола засвоєння учнями, i $€$ необхідними для вирішення науково-методичних задач $\mathrm{i}$ розвитку методики професійного навчання. Наприклад, до даної групи поняття «електричний ланцюг змінного струму» входить не як об'єкт дослідження технічної теорії, а як методико-технічне поняття - об'єкт пізнання учнів, частина змісту навчального матеріалу. Зміст цих понять у методичному вжитку суттєво відрізняється від технічного. Терміни у методичному вжитку часто спрощуються для підвищення доступності та видозмінюються залежно від рівня підготовки учнів. При розкритті змісту методико-технічних понять вказують на необхідність відбору навчального матеріалу и типові методи вивчення даного змісту [6].

Методичні поняття підрозділяються на чотири підгрупи.

1. Методичні поняття і терміни, що $є$ результатом розділу загальних дидактико-методичних понять. Наприклад, «урок виробничого навчання 3 вивчення трудових прийомів та операцій», «навчання кулінарії» - дидактикометодичні поняття, а «навчання читання електротехнічних схем», «навчання зняття розмірів»- методичні поняття.

2. Назви методів, методичних прийомів, характерних не для дидактики в цілому, а для навчання технічних дисциплін. На відміну від першої підгрупи ці терміни не $\epsilon$ результатом виокремлення із дидактико-методичних понять і не мають з ними прямих наслідкових зв'язків. До них відносяться, наприклад, «технічний диктант», «опис схеми поєднання елементів в електричних ланцюгах», «побудова креслень деталей», «розрахунок режимів різання» та ін.

Одні терміни виникли в результаті становлення методичної практики, наприклад, «усні задачі 3 опору матеріалів», «технічний диктант»; інші запозичені з виробничої сфери: «інструктаж», «технічний експеримент»і т.д. 
Журнал«Герспективитаінновації наукиљ

(Серія«Гедагогіка», Серія«ГЕихологія», Серія «Медицин»

№5(5) 2021

3. Назви різних засобів навчання технічних предметів (сюди входять назви різних демонстраційних приладів та механізмів, друкованих видань, що використовуються у процесі навчання), наприклад: «електромонтажна майстерня», «кабінет спеціальної технології», «робочий зошит 3 методів оптимізації» та ін.

4. Поняття та терміни з історії методики професійного навчання. До цієї групи входить порівняно невелика кількість понять, які вже не вживаються у повсякденній практиці навчання: «російська система виробничого навчання», «ручний метод обробки матеріалів» та ін.

У методиці професійного навчання можуть бути виділені численні явища, прийоми, методи, поняття яких ще не сформувались, а отже, немає відповідних їм термінів. Не мають назви багато вправ у виробничому навчанні, хоч вони вже давно сформувались у навчально-інструкційних картах. Не мають назв і не визначені як поняття рівні сформованості професійних знань та вмінь.

Висновки. Реалізація методів та прийомів професійного навчання $\epsilon$ відповідальністю як педагога-предметника, що викладає теорію професійних дисциплін, так і майстра виробничого навчання, який здійснює контроль над набуттям, удосконаленням та закріпленням практичних знань умінь та навичок учнів ПТНЗ. Спільна робота цих спеціалістів має бути злагодженою та доповнювати одна одну 3 метою уникнення розривів у повідомленні навчального матеріалу та суперечностей.

Методика професійної діяльності має свій понятійний та термінологічний апарат. Понятійна база цієї галузі педагогічної науки поділяється на три групи: дидактико-методичну, методико-технічну та власне методичну, - що знову підкреслює глибинний внутрішній зв'язок методики професійної освіти 3 широким спектром споріднених наук.

Також з історичної точки зору цікавим $є$ існування різних точок зору щодо змісту та призначення методичної діяльності педагога професійної освіти. Нами було названо класифікацію методичних понять за джерелами формування за допомогою яких продукти методичної діяльності викладача реалізуються в умовах уроку.

\section{Лimepamypa:}

1. Волкова Н.П. Педагогіка: посібник для студентів вищих навчальних закладів. - К.: Видавничий центр «Академвидав», 2005. - 560 с.

2. Дидактичні основи професійної освіти: підручник для студентів вищих навчальних закладів та педагогічних працівників системи професійно-технічної освіти / Олена Едуардівна Коваленко, Наталія Олександрівна Брюханова, Наталія Василівна Божко, Вікторія Вікторівна Бєлікова, Вероніка Борисівна Бакатанова ; Укр. інженерно-пед. акад.; за ред. Олена Едуардівна Коваленко. - Харків : Друкарня Мадрид, 2017. - 239с.

3. Методика трудового і професійного навчання та викладання загальнотехнічних дисциплін: навчальний посібник для вузів / Дмитро Олександрович Тхоржевський . - 3-е вид., перероб.і доп . - Київ : Вища школа, 1992 . - 334 с.

4. Ничкало Н. Педагогічна інноватика у профтехосвіти // Професійнотехнічна освіта. 2007. - № 3. - Спецвипуск. Всеукраїнська естафета інноваційних проектів. Лютий-червень 2007. - C. 69-71. 
5. Сидоренко В.К. Удосконалення підготовки вчителя загальнотехнічних дисциплін: Монографія. - К.: КДПІ, 1992. - 72 с.

6. Сидоренко В.К. Наукові основи професійного самовизначення школярів: Соціальнопсихологічні передумови вибору професії // Трудова підготовка в закладах освіти. - 1999. №1. - C.33-39.

\section{References:}

1. Volkova, N.P. (2005). Pedagogika [Pedagogy]. K.: Vidavnichij centr «Akademvidav» [in Ukrainian].

2. Kovalenko, Olena Eduardivna , Brjuhanova, Natalija Oleksandrivna , Bozhko, Natalija Vasilivna, Belikova, Viktorija Viktorivna, Bakatanova, Veronika Borisivna (2017). Didaktichni osnovi profesijnoï osvitu [Didactic bases of professional education]. - Harkiv : Drukarnja Madrid » [in Ukrainian].

3. Thorzhevs'kij, Dmitro Oleksandrovich (1992). Metodika trudovogo i profesijnogo navchannja ta vikladannja zagal'notehnichnih disciplin [Methods of labor and professional training and teaching of general technical disciplines]. Kiïv : Vishha shkola [in Ukrainian].

4. Nichkalo, N. (2007). Pedagogichna innovatika u proftehosviti [Pedagogical innovation in vocational education]. Profesijnotehnichna osvita - Vocational education, 3, 69-71 [in Ukrainian].

5. Sidorenko, V.K. (1992). Udoskonalennja pidgotovki vchitelja zagal'notehnichnih disciplin [Improving the training of teachers of general technical disciplines]. K.: KDPI [in Ukrainian].

6. Sidorenko, V.K. (1999). Naukovi osnovi profesijnogo samoviznachennja shkoljariv: Social'nopsihologichni peredumovi viboru profesiï [Scientific bases of professional self-determination of schoolboys: Socio-psychological preconditions of a choice of a profession]. Trudova pidgotovka $v$ zakladah osviti - Labor preparation in educational institutions, 1, 33-39 [in Ukrainian]. 